\title{
ANALISIS KEBIJAKAN PELESTARIAN DAMAR DI KABUPATEN PESISIR BARAT (STUDI TERHADAP AGENDA SETTING DAMAR SEBAGAI USAHA PERLINDUNGAN DAN PENINGKATAN KESEJAHTERAAN PETANI DAMAR)
}

\author{
lyaji Kolbinur \\ Jurusan Ilmu Administrasi Negara FISIP Universitas Lampung \\ email: iyajikolbinur@gmail.com \\ Simon S. Hutagalung \\ Jurusan Ilmu Administrasi Negara FISIP Universitas Lampung \\ email: soemandjaja@gmail.com
}

\begin{abstract}
ABSTRAK. Kabupaten Pesisir Barat memiliki kekayaan alam getah pohon getah dengan kualitas terbaik di dunia. Namun saat ini, keberadaan resin menyusut akibat penebangan kayu terus dilakukan. Mengacu pada permasalahan tersebut, agenda Pemerintah Daerah Kabupaten Pesisir Barat berkaitan dengan kebijakan konservasi resin di Kabupaten Pesisir Barat. Tujuan dari penelitian ini adalah memperoleh pengetahuan tentang teori penetapan agenda yang berkaitan dengan pelestarian dan kesejahteraan masyarakat petani resin. Di Kabupaten Pesisir Barat. Penelitian ini merupakan penelitian deskriptif dengan pendekatan kualitatif. Data dikumpulkan melalui wawancara, observasi, dan dokumentasi. Analisis data dilakukan dengan reduksi data, penyajian data dan kesimpulan atau verifikasi. Proses penetapan agenda kebijakan terkait pelestarian damar sudah ideal dan mengandung nilai kebijakan. Aktor yang terlibat sudah terpenuhi, aktor dan aktris sekaligus pejabat dan tidak resmi. Pemerintah daerah berperan aktif dalam menentukan masalah dan menentukan tujuannya. Selain itu, didominasi oleh nilai-nilai kebijakan dalam prosesnya. Rekomendasi yang bisa diberikan adalah membuat masyarakat lebih aktif terlibat dalam setiap agenda pemerintah, sehingga keputusan yang lahir akan diterima dan berjalan seperti yang diharapkan.
\end{abstract}

Kata kunci: Kebijakan Publik, Pengaturan Agenda, Regulasi Resin

\begin{abstract}
Pesisir Barat Regency has a natural wealth of resin tree sap with the best quality in the world. But currently, the existence of resin shrink caused by logging-logging continue to be done. Referring to the problems, the Local Government of Kabupaten Pesisir Barat agenda to issues related to conservation policies resin in the Pesisir Barat Regency. The purpose of this research is Gaining knowledge about agenda setting theory related to the issue preservation and welfare of the resin farming community in the Pesisir Barat Regency. This research is a descriptive study with qualitative approach. Data were collected through interviews, observation, and documentation. Data analysis was performed with data reduction, data presentation and conclusion or verification. The process of agenda setting policy related to the preservation of damar has been ideal and contains policy values. actors involved have been fulfilled, the actor and actress as well as official and unofficial. The local government plays an active role in defining the problem and determining the objectives. Additionally, dominated by the values of the policy in the process. The recommendations can be given is to make the public more actively involved in every government's agenda, so that the decisions that are born will be accepted and run as expected.
\end{abstract}

Keywords: Public Policy, Agenda Setting, Resin Regulation 


\section{A.PENDAHULUAN}

Repong merupakan istilah masyarakat Krui untuk menamakan kebun yang ditanami dan ditumbuhi berbagai jenis tanaman kayu dan buah-buahan. Jenis tanaman kayu yang ditanam merupakan jenis kayu keras dan berumur panjang. Dalam proses pengelolaan atau pemanfaatan repong pada akhirnya memunculkan tanaman yang mendominasi jumlahnya yakni repong damar. Repong damar adalah suatu sistem pengelolaan tanaman perkebunan yang ekosistemnya merupakan hamparan tanaman yang membentuk suatu hutan yang dibudidayakan dan dikelola oleh masyarakat (Nainggolan, 2011:39).

Damar merupakan komoditas unggulan masyarakat Krui yang terkenal sampai ke dunia internasional. Terutama kawasan Asia dan Eropa merupakan Negara tujuan ekspor damar mata kucing yang meliputi: India, Jerman, Philipina, Perancis, Belgia, Uni Emirat Arab, Bangladesh, Pakistan dan Italia. Repong damar yang ada di Kabupaten Pesisir Barat merupakan contoh keberhasilan sistem yang dirancang dan dilaksanankan sendiri oleh penduduk setempat dalam mengelola sumber daya hutan secara lestari dan menguntungkan.

Sistem ini cukup unik karena nyaris sempurna mengkonstruksi ekosistem hutan alam di lahan-lahan pertanian. Hal ini menunjukkan bahwa ekologi pohon damar sebagai sumberdaya ekonomi utama telah dikuasai dengan baik oleh penduduk setempat. Sistem ini terbukti mampu berreproduksi dalam jangka panjang, mendatangkan keuntungan ekonomi, dan memiliki landasan sosial yang kokoh. Damar tidak bisa dilepaskan dari kehidupan masyarakat Krui, Pesisir Barat. Sudah sejak 100 tahun lebih, warga di pesisir pantai yang menghadap Samudera Hindia ini membudidayakan pohon penghasil getah itu. Dari 70 desa yang tersebar di sepanjang Pesisir Krui, hanya 13 desa yang tidak memiliki repong damar. Lebih dari separuh penduduk Pesisir Krui terlibat dalam produksi damar. Baik sebagai pemilik repong, pedagang pengumpul, kuli angkut, pedagang besar damar, pengusaha angkutan, maupun buruh sortir. Maka tidak mengherankan 80 persen produksi resin damar Indonesia yang mencapai 10 ribu ton per tahun berasal dari Pesisir Krui. Damar mata kucing yang dihasilkan para petani damar di Krui merupakan yang paling banyak dicari pengekspor, sebab getah yang dihasilkan berkualitas tinggi. Namun belakangan ini pohon damar dengan kualitas getah terbaik di dunia yang berasal dari Kabupaten Pesisir Barat, terus mengalami penyusutan.

Dari sisi lingkungan hidup, eksistensi repong damar sungguh tidak bisa dianggap sepele. Kawasan yang membentuk hutan itu berfungsi sebagai daerah tangkapan air dan penstabil iklim. Repong damar selama ini berguna sebagai zone penyangga Taman Nasional Bukit Barisan Selatan (TNBBS). Berderet-deret pohon damar berdiri gagah, menjulang dengan rimbun. Sementara di belakangnya menghampar kawasan TNBBS, tempat konservasi aneka flora dan fauna.

Orang akan menyangka repongrepong damar itu hutan alam bagian dari kawasan TNBBS. Namun kenyataannya berada di luar kawasan konservasi. Salah satu yang menyebabkan repong damar yang ada di Kabupaten Pesisir Barat terus menerus mengalami penurunan adalah maraknya aksi illegal logging.

Sebagaimana yang telah dipaparkan diatas bahwa isu tentang keberlangsungan ketercukupan ekonomi dari para pelaku kegiatan konservasi sumberdaya alam semacam repong damar sangatlah rentan. Disinilah penting bagi pemerintah untuk memerankan fungsinya dalam membuat beragam kebijakan yang terkait dengan persoalan-persoalan kesejahteraan masyarakat petani damar dan kelestarian lingkungan yang ada di Kabupaten Pesisir Barat.

Bagaimanapun akhirnya, perjalanan inisiasi isu terhadap kesejahteraan ekonomi masyarakat petani damar dan pelestarian repong damar 
yang menjadi benteng bagi TNBBS hingga menjadi sebuah agenda kebijakan merupakan suatu hal yang penting untuk diteliti. Ketika sebuah masalah publik bertahan sekian lama dan belum ada solusi nyata, maka sudah menjadi kewajiban pemerintah untuk mewujudkannya menjadi sebuah kebijakan. Proses inisiasi pelestarian repong damar dan kesejahteraan masyarakat petani damar yang terjadi di Kabupaten Pesisir Barat hingga masuk ke ranah kebijakan dapat dikatakan sebagai proses inisiasi kebijakan yang berjalan tanpa suatu hambatan berarti. Pro dan kontra tetap ada, namun tidak terlalu banyak menghalangi jalannya inisiasi kebijakan hingga menjadi agenda kebijakan.

Oleh karena itu, penelitian ini dilakukan untuk mengetahui bagaimana proses dari mulai masalah muncul dan dirasakan oleh masyarakat Kabupaten Pesisir Barat, hingga kemudian diinisiasi dan pada akhirnya ditetapkan menjadi agenda kebijakan yang akan disahkan oleh pemerintah.

Berdasarkan uraian diatas, maka rumusan masalah dalam penelitian ini adalah; bagaimana proses agenda setting terhadap isu pelestarian dan kesejahteraan masyarakat petani damar di Kabupaten Pesisir Barat?

\section{B.METODE PENELITIAN}

Penelitian ini menggunakan pendekatan kualitatif secara umum yakni prosedur penelitian yang menghasilkan data-data deskriptif berupa kata-kata tertulis. Bogdan dan Taylor dalam Moleong (2005:4) mendefinisikan penelitian kualitatif sebagai prosedur penelitian yang menghasilkan data deskriptif berupa kata-kata tertulis atau lisan dari orang-orang dan perilaku yang dapat diamati. Pendekatan ini tidak boleh mengisolasi individu atau organisasi ke dalam variabel atau hipotesis tetapi harus dipandang sebagai bagian dari keutuhan.

Dengan menggunakan pendekatan kualitatif deskriptif, penulis bermaksud ADMINISTRATIO untuk memaparkan mengenai gejalagejala yang terdapat di dalam masalah penelitian yaitu menganalisis dan mendeskripsikan perumusan tentang agenda setting kebijakan pelestaraian repong damar di Kabupaten Pesisir Barat.

Dalam penelitian ini, peneliti memfokuskan pada proses agenda setting mengenai isu kesejahteraan masyarakat petani damar dan tentang Pelestarian Repong damar untuk masuk kedalam agenda kebijakan pemerintah Kabupaten Pesisir Barat yang dijabarkan sebagai berikut:

1. Aktor-aktor yang terlibat di dalam proses agenda setting

a. Official actors

b. Unofficial actors

2. Dinamika dari peran pembuat kebijakan dalam proses agenda setting terhadap isu pelestarian dan kesejahteraan masyarakat petani damar
a. Tindakan pemerintah
b. Nilai-Nilai

\section{C.HASIL DAN PEMBAHASAN}

Aktor-aktor atau pemeran serta dalam proses pembentukan kebijakan peles-tarian repong damar dapat dibagi ke dalam dua kelompok, yakni para pemeran serta resmi (official actors) dan para pemeran serta tidak resmi (unofficial actors):

\section{Official Actors}

Biasanya juga disebut dengan pembuat kebijakan resmi dalam sebuah kebijakan. Artinya aktor yang memiliki kewenangan legal dan sah menurut undang-undang untuk terlibat dalam perumusan kebijakan publik. Pemeran serta resmi dalam isu kebijakan pelestarian repong damar di Kabupaten Pesisir Barat ini terdiri dari aktor eksekutif yakni Dinas Kehutanan dan Perkebunan serta aktor legislatif yakni komisi b DPRD Kabupaten Pesisir Barat.

\section{Unofficial Actors}


Selain dari lembaga-lembaga seperti eksekutif dan legislatif yang secara formal membuat kebijakan publik, masih ada elemen lain yang berpartisipasi dalam proses kebijakan, diantara pemeran serta tidak resmi, diantaranya kelompok kepentingan (NGO). Mereka dikenal sebagai partisipan non-pemerintah karena bagaimanapun elemen ini dianggap penting, walau pada dasarnya mereka tidak memiliki wewenang yang sah untuk membuat kebijakan publik. Satu-satunya Pemeran serta tidak resmi dalam isu kebijakan pelestarian repong damar di Kabupaten Pesisir Barat ini ialah PMPRD.

Berdasarkan hasil penelitian, ide tau gagasan terkait pelestarian repong damar sebenarnya muncul ketika Kabupaten Pesisir Barat masih menjadi bagian dari Lampung Barat, kemudian pada saat Kabupaten Pesisir Barat lahir dan di pimpin oleh pejabat Bupati Pesisir Barat yakni bapak Qodratul Ikwan isu terkait pelestarian repong damar mulai terus disuarakan lagi. Terlebih Pohon damar merupakan salah satu ikon dari kabupaten termuda di Lampung ini. Pemerintah daerah Kabupaten Pesisir Barat sejak awal telah berupaya menjaga keberadaan repong damar dengan melakukan program rehabilitasi repongrepong damar masyarakat dengan setiap tahun memberikan bantuan bibit.

Selain itu, pemerintah daerah juga sempat mengeluarkan surat edaran dengan No:552/366a/III.11/2015 terkait himbauan untuk melestarikan tanaman rakyat pohon damar. Terkait upaya melahirkan sebuah produk kebijakan Peslestarian repong damar di Kabupaten Pesisir Barat pemerintah daerah sendiri telah mengusulkan kepada DPRD Kabupaten Pesisir Barat untuk dibahas dalam prolegda (program legislasi daerah) di tahun 2016 ini.

a. Dengan demikian dapat disimpulkan bahwa pemerintah daerah Kabupaten Pesisir Barat berperan aktif dalam mendifinisikan permasalahan pelestarian repong damar serta menentukan tujuan-tujuan. Hal ini sesuai pada pilihan peran pemerintah
Kabupaten Pesisir Barat yakni Make It Happen seperti yang dikemukakan oleh Jhon, bahwa pejabat pemerintah tidak sampai menunggu sistem bekerja tetapi pembuat kebijakan juga mengarahkan beroprasinya sistem tersebut.

Dengan demikian, proses agenda setting terhadap kebijakan pelestarian repong damar tersebut tidak dihadapkan pada suatu hambatan yang berarti, karena isu kebijakan yang dipilih benar-benar penting dan mempunyai dampak besar bagi masyarakat di Kabupaten Pesisir Barat yang menggantungkan kehidupannya sebagai petani damar juga menjaga keseimbangan hutan di Kabupaten Pesisir Barat. Selain itu, isu kebijakan pelestarian repong damar ini memang telah menjadi perhatian para pembuat kebijakan baik official actors maupun unofficial actors dengan rencana kerja politik dan kemungkinan besar isu kebijakan pelestarian repong damar ini dapat dipecahkan.

Hal ini telah diperhatikan dan dipenuhi. Proses agenda setting terkait pelestarian repong damar di Kabupaten Pesisir Barat tidak saja lancar atau ditemukan hambatan yang cukup berarti, tetapi juga memberikan corak dan warna pada proses selanjutnya karena peran pemerintah daerah yang aktif serta hasil kebijakan yang dipilih benarbenar dapat memecahkan masalah yang tumbuh kembang di masyarakat. Disinilah pentingnya pemerintah daerah berperan dengan baik, untuk nantinya dapat menghasilkan rumusan kebijakan yang tepat karena proses agenda setting yang juga sesuai.

b. Berdasarkan hasil penelitian, kebijakan pelestarian repong damar di Kabupaten Pesisir Barat, tentu tidak terlepas dari nilai-nilai di dalamnya. Melalui keseluruhan-nya bahwa para pembuat keputusan menunjukan kebijakan yang 
diputuskan tersebut adalah untuk kepentingan masyarakat, akan tetapi di dalam perumusan kebijakan pelestarian repong damar pembuat keputusan belum mampu menyediakan pilihan alternatif kebijakan dalam proses penyelesaian yang terjadi di masyarakat.Pemerintah Kabupaten Pesisir Barat saat ini telah melakukan suatu tindakan yang dibutuhkan masyarakat itu sendiri yakni melahirkan suatu produk kebijakan berupa peraturan daerah yang dapat menjamin keberadaan repong damar masyarakat juga menjaga lingkungan. Oleh karena itu, kebijakan pelestarian repong damar ini mengandung nilai-nilai kebijakan, dimana dalam hal ini keputusan dibuat atas dasar persepsi tentang kepentingan publik.

Nilai adalah sesuatu yang dianggap bermanfaat bagi masyarakat. Para aktor baik yang berasal dari kalangan pemerintah maupun nonpemerintah terlibat dengan persoalan nilai dalam proses agenda setting. Dalam kaitannya dengan isu kebijakan pelestarian repong damar kebijakan mau tidak mau haruslah memperhitungkan multi nilai (multiple values). Namun pemerintah daerah Kabupaten Pesisir Barat bertindak dengan baik atas dasar persepsi mereka tentang kepentingan masyarakat atau kepercayaankepercayaan mengenai apa yang merupakan kebijakan publik secara moral benar atau pantas. Sehingga jika kebijakan lahir atas dasar nilai yang disepakati bersama ini juga didasarkan pada nilai-nilai kebijakan yang berjalan didalam proses agenda setting yang baik pula. Tentunya kebijakan yang dihasilkan nantinya terkait pelestarian repong damar ini akan memiliki implikasi nilai, baik secara tersirat maupun berterus terang. Maka akan menciptakan hasil yang maksimal dalam proses agenda setting.

\section{D.KESIMPULAN DAN SARAN}

\section{Kesimpulan}

Dari hasil penelitian maka dapat disimpulkan hal-hal sebagai berikut:

1. Aktor yang terlibat dalam proses agenda setting kebijakan pelestarian repong damar di Kabupaten Pesisir Barat antara lain adalah, dinas Kehutanan dan Perkebunan Kabupaten Pesisir Barat, dan Persatuan Masyarakat Petani Repong Damar (PMPRD) yang banyak berperan di tahap awal. Aktor yang terakhir adalah Dewan Perwakilan Rakyat Daerah (DPRD) Kabupaten Pesisir Barat yang memiliki peran sebagai pemegang legitimasi untuk memasukkan isu perlinndungan pohon damar terhadap kelestarian lingkungan ke dalam agenda kebijakan pemerintah legislatif (prolegda). Antara pemerintah eksekutif dan para NGO cendrung memiliki hubungan yang lebih dekat. Sedangkan hubungan antara pemerintah eksekutif dan legislatif kurang terjalin dengan baik, karena kurangnya komunikasi diantara keduanya.

2. Peran yang dimainkan Pemerintah Daerah Kabupaten Pesisir Barat terhadap agenda setting kebijakan pelestarian repong damar adalah menjadikan hal itu kenyataan (make it happen) yakni dengan peran aktif yang dilakukan pemerintah Kabupaten Pesisir Barat. Pj.Bupati Pesisir Barat bapak Qodratul Ikwan beliau menyatakan bahwa pemerintah daerah telah mengusulkan kepada DPRD untuk dibahas dalam prolegda (Program Legislasi Daerah) di tahun 2016 ini. Ide atau gagasan ini kemudian dimatangkan oleh berbagai kajian ilmiah yang dilakukan oleh kalangan partisipatif dan instansiinstansi terkait bekerjasama dengan kalangan teknokratik yang melibatkan para akademisi dari perguruan tinggi yang selanjutnya dipublikasikan. 
Masalah nilai atau values dalam analisis kebijakan publik, pada umumnya akan menyentuh aspek metapolicy, karena menyangkut hakikat, perspektif, sikap,dan prilaku yang tersembunyi atau yang dinyatakan secara terbuka dari aktoraktor yang bertanggung jawab dalam perumusan atau pembuatan kebijakan publik menurut Hodgkinson dalam Wahab (2012:108). Proses kebijakan pelestarian repong damar di Kabupaten Pesisir Barat lebih dimuat oleh nilai-nilai kebijakan. Karena pada kenyataannya memang nilai kebijakan yang merupakan salah satu kategori nilai dalam sebuah kebijakan telah Nampak dalam kebijakan pelestarian repong damar di Kabupaten Pesisir Barat.

\section{SARAN}

1. Kurang baiknya jalinan komunikasi antar lembaga pemerintah, khususnya antara Dinas Kehutanan dan Perkebuanan dengan DPRD Kabupaten Pesisir Barat justru merupakan salah satu hambatan yang cukup berarti dalam upaya melahirkan kebijakan terkait pelestaraian repong damar di Kabupaten Pesisir Barat. Terlebih lagi masyarakat sendiri sudah mulai kritis dalam menyikapi persoalan-persoalan penebangan yang terus-menerus dilakukan oleh orang-orang yang tidak bertanggung-jawab. Oleh karena itu, seharusnya komunikasi intensif antara Dinas Kehutanan dan Perkebunan dengan DPRD Kabupaten Pesisir Barat dapat terjalin dengan baik. Kemudian lembaga swadaya masyarakat, baik itu dari kalangan ornop maupun kelompok masyarakat seperti PMPRD Kabupaten Pesisir Barat harus mampu menjaga keberlanjutan usahanya serta terus bersinergi dengan pemerintah daerah dalam upaya pelestaraian repong damar dengan tetap menjaga kredibilitas dan tetap menomorsatukan kepentingan rakyat serta tetap mengacu pada peraturan perundangan yang berlaku. Seharusnya masyarakat lebih intens dilibatkan dalam setiap kegiatan ataupun program-program riil lainnya.

2. Berdasarkan nilai-nilai yang terkandung dalam proses perumusan kebijakan pelestarian repong damar di Kabupaten Pesisir Barat, sebaiknya isu kebijakan pelestarian repong damar di Kabupaten Pesisir Barat dapat segera dibentuk formulanya. Karena kebijakan pelestarian repong damar tersebut memung-kinkan untuk dilaksanakan dan tentunya dapat menyelesaikan persoalan-persoalan yang ada di masyarakat serta melibatkan aktif masyarakat dalam segala proses kebijakannya. Maka akan lebih baik jika hal tersebut dilaksanakan terlebih lagi memiliki tujuan menguntungkan kepentingan publik. Selain itu mampu mengatasi dan mengantisipasi perubahan yang akan terjadi di masa yang akan datang.

\section{DAFTAR PUSTAKA}

\section{Buku}

Agustino, Leo. 2014. Dasar-Dasar Kebijakan Publik. Bandung: Alfabeta

Birkland, Thomas. 2005. An introduction to the policy procees (theories, concept and models of public policy making). New York

Dunn, William N. 2003. Pengantar Analisis Kebijakan Publik. Yogyakarta: Gadjah Mada University Press

Hamdi, Muchlis. 2014. Kebijakan Publik: Proses, Analisis, dan Partisipasi. Bogor: Ghalia Indonesia

Idrus, Muhammad. 2007. Metode Penelitian Ilmu-Ilmu Sosial : Pendekatan Kualitatif dan Kuantitatif. Yogyakarta: UII Press Yogyakarta

Koestoro, Budi dan Basrowi. 2006. Strategi Penelitian Sosial dan Pendidikan. Surabaya: Media Oetama Press 
Firdalia dan Bambang Utoyo Sutiyoso, Penangangan Sengketa Tanah...

Kusumanegara, Solahuddin. 2010. Model dan Aktor dalam Proses Kebijakan Publik. Yogyakarta: Gava Media

Moleong, Lexy J. 2005. Metodelogi Penelitian Kualitatif. Bandung: PT. Remaja Rosdakarya Offset

Nugroho, Riant. 2011. Public Policy. Jakarta: Gramedia

Parsons, Wayne. 2014. Pengantar Teori dan Praktik Analisis Kebijakan. Jakarta: Kencana Prenadamedia Group

Sugiyono. 2010. Metode Penelitian Kuantitatif, Kualitatif dan R7\&D. Bandung: Alfabeta

Suharto, Edi. 2013. Kebijakan Sosial Sebagai Kebijakan Publik. Bandung : Alfabeta

Wahab, Solichin Abdul. 2012. Analisis Kebijakan dari Formulasi ke Penyusunan Model-Model Implementasi Kebijakan Publik. Jakarta: PT Bumi Aksara

Widodo, Joko. 2013. Konsep dan Aplikasi Analisis Proses Kebijakan Publik. Malang: Bayumedia Publishing

Winarno, Budi. 2012. Kebijakan Publik (Teori, Proses, dan Studi Kasus). Yogyakarta: C A P S

\section{Jurnal/ Skripsi/ Dokumen - Dokumen}

Herawati, Tuti. 2012. Perjalanan Multiabad Repong DamarKajian Aspek Tata Guna Lahan. Jurnal: Badan Litbang Kementerian Kehutanan

Juhadi. 1995. “Repong Damar" Sistem Pengelolaan Sumberdaya Hutan Berkelanjutan di desa way sindi krui Lampung Barat. Skripsi: Universitas Indonesia

Lubis, Zulkifli. 1997. Repong Damar :

Kajian Tentang Pengambilan

Keputusan dalam Pengelolaan

Lahan Hutan di Pesisir Krui,
Lampung Barat. Bogor: Center For International Foresty Research.

Michon, G., de Foresta H., Kusworo A. and P. Levang (2000). Chapter 7. The Damar Agro-Forests of Krui, Indonesia: Justice for Forest Farmers. In C. Zerner (Editor): People, Plants and Justice. Columbia University Press.

Nainggolan, Valentina. 2011. Analisis Populasi Jenis Primata di Repong Damar Pekon Pahmungan Kecamatan Pesisir Tengah Krui Lampung Barat. Bandar Lampung: Unila (Skripsi).

Purwanto, Hadi. 2015. Analisis Kebijakan Pemindahan Pusat Pemerintahan Dari Kota Bandar Lampung ke Kabupaten Lampung Selatan Sebagai Upaya Pemerataan Pembangunan Dan Perubahan Ekonomi Masyarakat. Skripsi:Universitas Lampung

\section{Website}

http://cybex.pertanian.go.id/materilokal ita/detail/5160 di akses pada 13 September 2015 Pukul 16.13 WIB

http://www.lampost.co/berita/populasipohon-damar-di-pesisir-baratterus menyusut di akses pada 23 Agustus 2015 Pukul 00.19 WIB

http: / / www.mongabay.co.id/2015/04/29 /hutan-damar-terjaga-namun warga masih-belum-sejahtera/ di akses pada 25 Agustus 2015 Pukul 20.00 WIB

http://www.terasLampung.com/2014/05 /repong-damar-krui-pernah-terancamaksi.html

di akses pada 25 Agustus 2015

Pukul 20.45 WIB 
Jurnal Ilmiah Administrasi Publik dan Pembangunan, Vol. 7 No. 1, Januari-Juni 2016 